\title{
Courtyard Design in Schools and its Influence on Students' Satisfaction
}

\author{
Dr. Muna Salameh ${ }^{1}$, Dr. Basim Touqan ${ }^{2}$, May Salameh ${ }^{3}$ \\ ${ }^{1}$ Ajman University \\ Ajman, UAE \\ m.salameh@ajman.ac.ae ; basem.tuqan@siemens.com \\ ${ }^{2}$ Siemens LLC \\ Dubai, UAE \\ mayluli1994@gmail.com
}

\begin{abstract}
The courtyard as architectural passive design strategy has proved its capability of enhancing the thermal conditions of buildings. Apart from the good thermal impacts of the courtyard, there are other effects that were not tapped and need to be explored such as the satisfaction of the courtyard's users in terms of psychological and wellbeing factors. This study attempts to investigate and assess the relationship between the existing design of the school courtyards in UAE with the students' satisfaction. A self-administrated questionnaire was distributed between students of secondary classes in two private schools in UAE to gather the data. Six hypotheses were developed to explore and validate the mentioned relationship; SPSS (Statistical Package for Science Software) program was used to apply several tests such as regression analysis to examine the developed hypotheses. The results showed high relationship significance between the School Courtyard Design and Students' Satisfaction, so that the courtyard design can shape the student satisfaction as global variable with $29.2 \%$, with many other important findings. The work opens the door for architects and school principals alike to understand the effect of the school courtyard design on students' satisfaction, which consequently leads to better academic achievement.
\end{abstract}

Keywords: Courtyard's design, SPSS, UAE, Social health, Student satisfaction.

\section{Introduction}

The consumption of energy in the world is increasing extremely because of population growth and because of the technology development in all aspects of life. The high-energy consumption -especially by buildings negatively affected the environment and the general health. Nations by time realized the importance of adopting passive design solutions like courtyards in preserving energy [1], [2].

Courtyard is one of passive design strategies that were used since thousands of years in public and private buildings [3], [4]. Edwards [5] stated that courtyard was developed as a result of interaction between the building and the environment to provide thermal comfort for the building and natural ventilation without energy consumption especially in hot arid places like UAE [6], [7], [8]. Several schools in UAE have courtyards in the center of the building as a core for the arrangement of the classes and the facilities. The courtyard in the school provides private outdoor environment for students' activities, space for playing and relaxation in the break time. Many researches were conducted for the purpose of examining the influence of courtyards thermal behavior and ventilation on the interior spaces around it [9], [10], [11], [12], [13]. Most of the researchers who addressed courtyards discussed and highlighted the courtyard positive effect on the environment of the building; however, there was no approach regarding courtyard psychological and mental effect on the occupants, especially in schools. In this research a quantitative analysis will be conducted to discuss the effect of the courtyards in schools on the satisfaction of the students, which therefore affects their educational achievement. The satisfaction of the students is very important issue in the educational process because of its effects on the student's behavior and achievement in school. Brown and Mazzarol [14] declared that the institutional appearance affects the satisfaction of the students thus their loyalty and achievement, on the other hand Grossman and Goodhart [15] discussed the importance of the student satisfaction in supporting student relations and motivations. 


\section{Literature Review}

\subsection{Courtyards and schools}

Courtyards can provide motivations for users' happiness, comfort, relaxing and socialization [16], [17]. Rigolon [18] mentioned in his study that schools courtyards were included strongly in the school designing discussions; moreover he focused in his study on school buildings that presented innovative factors in the field of spaces for learning and socializing. Evaluating the students' satisfaction is an important process for the education practitioners so they can review the best methods of teaching techniques based on best measures for students' satisfaction [19].

\subsection{Student Satisfaction}

The satisfaction of the students is an important driver for better educational achievement. The student satisfaction can be achieved within the school building by better social interaction, enhanced learning motivations, mental and physical comfort, and pleasant outdoor space. Uline and Tschannen-Moran [20] affirmed in their study that the physical environment of the school including the building characteristics, facilities and design affect the social atmosphere thus the educational achievement and their general satisfaction. Martirosyan [21] stated that the students' satisfaction is essential for better educational achievement. Courtyards can improve the students' level of socialization, mental and physical well-being, and happiness [22].

Social interaction is a key factor for student satisfaction in schools; because of that it is integrated it in the educational plan. Gidlöf-Gunnarsson and Öhrström [23] stated that the courtyard can improve the social interaction of the users and can give a sense of relaxation. Kolozali and Kolozali [24] Stated that the courtyard is essential in the passive and active social life for the students. Salameh [7] and Rigolon [18] insisted on the importance of the presence of the courtyard space in a school building as an innovative reason for a better social and education atmosphere.

Hawker [25] conducted a study that confirmed the positive link between the physical fit and the mental wellbeing of the students in a school. On the other hand, Markus et al. [26] pointed to the courtyard as a space for physiological health. Thus, school's courtyard is important in any school design plan to achieve health fitness and mental wellbeing among school students.

Matsuoka [27] mentioned the direct effect of landscaping within the school building courtyard as a pleasing outdoor space that positively impacts on student satisfaction as it can reduce mental stress and tension. Lau and Yang [28] mentioned that natural features in the courtyard can improve the students' senses, meditation and mental well-being, and motivation. Therefor the courtyard can be perceived as a major part for students' motivation towards the educational process. Matsuoka and Kaplan [29] turned to the fact that landscape in the open spaces provides the users with comfort thus it can be perceived as pleasant outdoor space, which can be reflected on student educational behavior. Eddy [30] insisted that the courtyards are essential outdoor spaces in schools, as they provide the students with pleasant outdoor spaces for playing, socializing and relaxation. Furthermore, they engage students into a real scientific outdoor lab about plants and climates. Additionally, he added that a courtyard with a suitable design could inspire the students and improve their educational achievements. Therefore, integrating natural in the courtyard can convert it to a pleasant outdoor space and can be considered as a reason for students' satisfaction.

\section{Conceptual Framework}

Based on previous literature review the study model was established as shown in (Figure1). There are six main developed hypotheses to examine the connection between the "School Courtyard Design" and "Student Satisfaction" as global variables beside examining the connection between their facets. The hypotheses are explained in the following statement: H1: A strong connection is hypothesized between "Student Satisfaction" 
and "School Courtyard Design". Nevertheless, additional five sets of hypotheses were developed so that each set consists of three sub hypotheses identified table 1 .

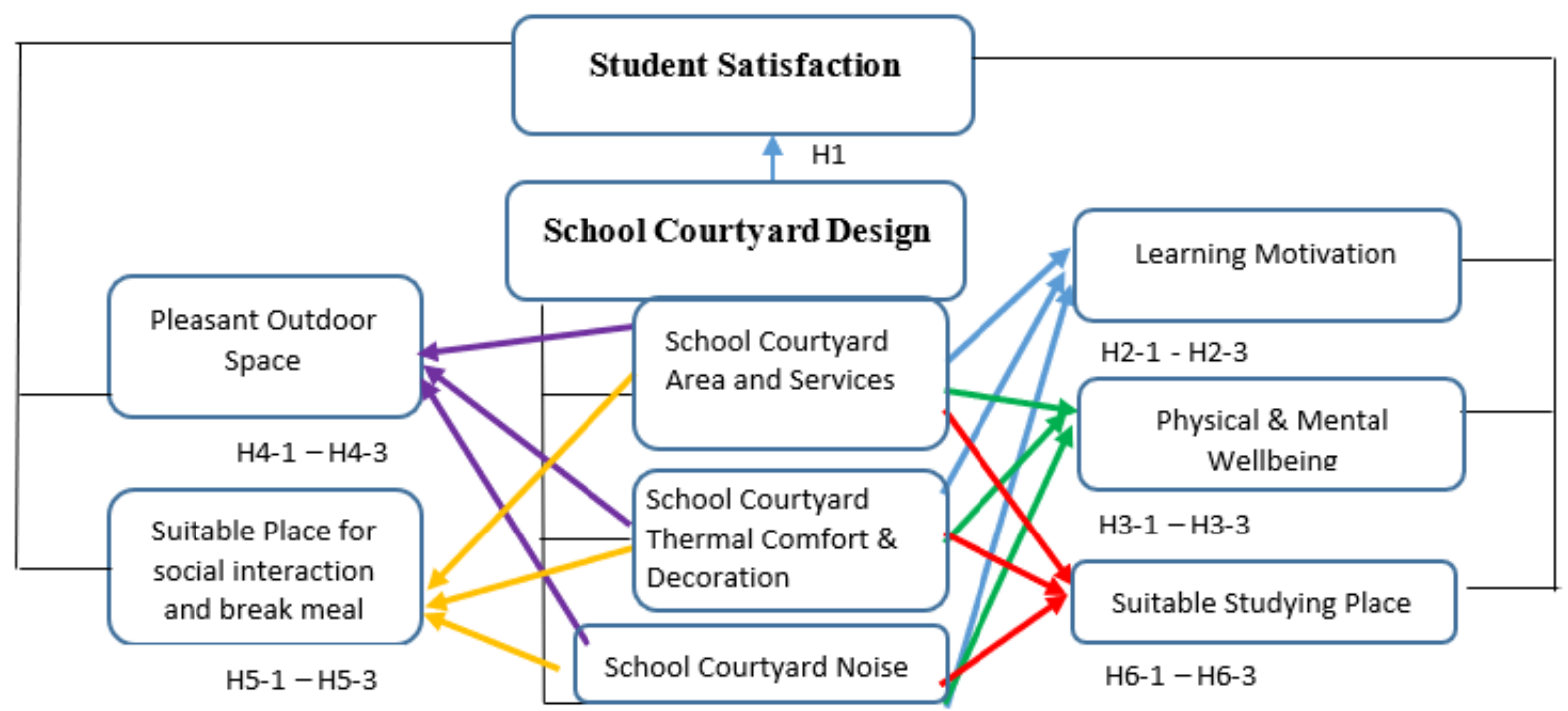

Fig. 1: The six main developed hypotheses of the research.

Table 1: The six main developed hypotheses of the research.

\begin{tabular}{|c|c|}
\hline \multicolumn{2}{|c|}{ The six main developed hypotheses of the research } \\
\hline $\begin{array}{l}\text { H1: A strong connection is hypothesized between "Student } \\
\text { Satisfaction" and "School Courtyard Design". }\end{array}$ & $\begin{array}{l}\text { H2-1: A strong connection is hypothesized between "Learning } \\
\text { Motivation" and "School Courtyard Area and Services" } \\
\text { H2-2: A strong connection is hypothesized between "Learning } \\
\text { Motivation" and "School Courtyard Decoration and } \\
\text { Environmental Comfort" } \\
\text { H2-3: A strong connection is hypothesized between "Learning } \\
\text { Motivation" and "School Courtyard Noise" }\end{array}$ \\
\hline $\begin{array}{l}\text { H3-1: A strong connection is hypothesized between "Physical } \\
\text { and Mental Well-being" and "School Courtyard Area and } \\
\text { Services" } \\
\text { H3-2: A strong connection is hypothesized d between } \\
\text { "Physical and Mental Well-being" and "School Courtyard } \\
\text { Decoration and Environmental Comfort" } \\
\text { H3-3: A strong connection is hypothesized between "Physical } \\
\text { and Mental Well-being "and "School Courtyard Noise" }\end{array}$ & $\begin{array}{l}\text { H4-1: A strong connection is hypothesized between "Pleasant } \\
\text { Outdoor Space" and "School Courtyard Area and Services" } \\
\text { H4-2: A strong connection is hypothesized between "Pleasant } \\
\text { Outdoor Space" and "School Courtyard Decoration and } \\
\text { Environmental Comfort" } \\
\text { H4-3: A strong connection is hypothesized between "Pleasant } \\
\text { Outdoor Space" and "School Courtyard Noise" }\end{array}$ \\
\hline $\begin{array}{l}\text { H5-1: A strong connection is hypothesized between "Suitable } \\
\text { place for social interaction and break meal" and "School } \\
\text { Courtyard Area and Services" } \\
\text { H5-2: A strong connection is hypothesized between "Suitable } \\
\text { place for social interaction and break meal" and "School } \\
\text { Courtyard Decoration and Environmental Comfort" } \\
\text { H5-3: A strong connection is hypothesized between "Suitable } \\
\text { place for social interaction and break meal" and "School } \\
\text { Courtyard Noise }\end{array}$ & $\begin{array}{l}\text { H6-1: A strong connection is hypothesized between "Suitable } \\
\text { Studying Place" and "School Courtyard Area and Services" } \\
\text { H6-2: A strong connection is hypothesized between "Suitable } \\
\text { Studying Place" and "School Courtyard Decoration and } \\
\text { Environmental Comfort" } \\
\text { H6-3: A strong connection is hypothesized between "Suitable } \\
\text { Studying Place" and "School Courtyard Noise. }\end{array}$ \\
\hline
\end{tabular}




\section{Research Methodology}

This section will discuss the methods and processes adopted to implement the research work and to examine the study's hypotheses.

\subsection{Research's sample}

Primary data of this research was obtained from the feedback on self-administrated questionnaire filled by high school students from two schools located in the Emirate of Sharjah in UAE. The collected complete questionnaires were 296 only out of 450 with response rate of $65 \%$, however five of them were discarded as the data obtained was invalid, so that the final sample size ended with 291 students. The sampling error was calculated and found to be $5.7 \%$ based on a calculated margin error matching confidence of $95 \%$.

\subsection{Study's Instrument}

The tool implemented in this research was a questionnaire. The questionnaire consisted of three parts. Part one was pertaining to demographic information. Demographic questions were developed in order to pre-screen the demographic information such as "Gender" and "School grade". Part two was pertaining to the factors of the "School Courtyard Design" and was consisted of 12 items. Part three was pertaining to the factors of "Student Satisfaction" and was consisted of 17 items. All the items were developed and determined according to the survey objectives, the conventions of the researches and other related references. Likert's five-point scale was used to evaluate all the questions of part two and part three, i.e. highest is "strongly agrees" 5 and the lowest is 1 for "strongly disagree".

\subsection{Study variables and measures}

The study was based on two major or global variables, "School Courtyard Design" as Independent variable and "Student Satisfaction" as Dependent variable. Both variables were assumed to be multidimensional which will be investigated in the factor analysis test, the study model is illustrated in previous (Figure 1). The model shows the layout of the variables and factors along with relationships between each other. The independent variable "School Courtyard Design" was dimensioned by three factors which are: "School Courtyard Area and Services", "School Courtyard Thermal Comfort \& Decoration" and "School Courtyard Noise", the independent factors were measured by 12 items. On the other hand, the dependent variable "Student Satisfaction" was dimensioned by five factors which are: "Learning Motivation", "Physical \& Mental Wellbeing", "Pleasant Outdoor Space", "Suitable place for social interaction and break meal" and "Suitable studying place"; the dependent factors were measured by 17 items.

\subsection{Statistical analysis}

The survey data were correctly coded then different tests were implemented through SPSS. Reliability test was conducted to evaluate the reliability of the questionnaire [31]. Furthermore, factor analysis test was employed to examine the global variables multidimensionality and whether the items forming the factors of

global variables were valid or not. Besides that, Pearson Chi Square test was conducted between demographic data with Independent factors to investigate the relationship between the demographic variables and independent factors of the courtyard design. regression analysis test was used for further investigation regarding the relationships between Independent and Dependent global variables and the links between the independent facets with dependents facets.

\section{Interpretation of the Resulted Data and Discussions}

In this section, the data obtained was processed by SPSS (Statistical Package for Science Software) program to analyze the data and to read behind the statistics. The following items were regarded to be texted in the questionnaire in a negative meaning: "The courtyard can be sometimes a source of noise for some classrooms" and "The courtyard can be sometimes a source of distraction for the students \& teachers in the classrooms", hence the obtained answers (from 1 to 5) of both items were reversed and recoded. 


\subsection{Descriptive Statistics}

In this part, the demographic frequencies along with percentages were presented to see the pattern of frequency distribution. As far as the gender is concerned, the number of female students responded to the questionnaire was greater than the males (174 female students with 59.8\% of total respondents versus 117 male students with $40.2 \%$ of total respondents).

Table 2: Frequency and percentage of demographic variables.

\begin{tabular}{|l|l|l|}
\hline Gender & Frequency & ercentage \% \\
\hline Female & 174 & $59.80 \%$ \\
Male & 117 & $40.20 \%$ \\
Total & 291 & $100.00 \%$ \\
\hline
\end{tabular}

\subsection{Factor analysis}

As per the discussions presented in literature review of the study, Independent and dependent variables have been concluded to be multidimensional variables; however factor analysis test via SPSS program is employed to examine the global variables multidimensionality and whether the items forming the factors of global variables are valid or not. Berk et al. [32] has turned to the factor analysis and how a variable can be structured, as they stated that factor analysis is a method that filters and discards the weak correlated items that cannot be valid to represent and measure the factor. SPSS in factor analysis process calculates the correlation of the items, rotate, and load them under a factor; the cut off value for correlation is 0.5 , no matter whether the score is positive or negative. Table-3 shows the outcome of factor analysis varimax rotation conducted on Independent variable of 12 items, the 3 dimensions of "School Courtyard Design" variable were successfully loaded but with 9 items only scoring above 0.5 on the varimax rotation. These factors were "School Courtyard Area and Services" (F1), "School Courtyard Environmental Comfort \& Decoration" (F2) and "School Courtyard Noise" (F3), however 2 items were completely dropped from (F2) and one item from (F3) as they were scoring less than 0.5 . Based on that the factors were recomputed by excluding these items, so that they were excluded also from all the further analysis when using regressions tests.

Table 3: Factor loading of school courtyard Design.

\begin{tabular}{|l|l|l|l|}
\hline Independent variable items & \multicolumn{2}{|l|}{ Component } \\
\cline { 2 - 4 } & 1 & 2 & 3 \\
\hline Environmental_Decoration-1 & 0.593 & & \\
Environmental -Decoration_2 & & & \\
Environmental -Decoration_3 & & \\
Environmental -Decoration_4 & & \\
Environmental -Decoration_5 & & \\
Environmental -Decoration_6 & & \\
Area_Services_1 & & \\
Area_Services_2 & & \\
Area_Services_3 & & \\
Area_Services_4 & & \\
Courtyard_Noise_1 & & \\
Courtyard_Noise_2 & & \\
\hline
\end{tabular}

Similarly, factor analysis test has been conducted on the factors related to the dependent variable. Table- 4 displays the outcome of factor analysis varimax rotation conducted on dependent variable of 17 items. The 5 dimensions of "Student Satisfaction" variable were successfully loaded, but with 16 items only scoring above 0.5 on the varimax rotation, these factors are : "Physical \& Mental Wellbeing" (F1), "Pleasant Outdoor Space" (F2), "Learning Motivation" (F3), "Suitable place for social interaction and break meal" (F4) and " Suitable 
Studying Place" (F5), on the other hand one item from (F1) was dropped as it was scoring less than 0.5. It can be noted that item 1 and 5 from (F2) were loaded in (F4) which can be merged and recomputed in (F4) but before taking any action regarding re-labeling and re-computing of (F4), a proactive step has been conducted by carrying out early reliability test on (F4) items including the 2 items from $(\mathrm{F} 2)$. The result of the test showed that items of new (F4) can be reliable only if items 1 and 5 of the original (F2) are dropped, thus these items were completely dropped from all factors, and were not considered in any further significance tests, thus final number of dependent variable items reached by factor analysis process were 14 items.

Table 4: Factor loading of student satisfaction.

\begin{tabular}{|l|l|l|l|l|l|}
\hline Dependent variable items & \multicolumn{2}{|l|}{ Component } \\
\cline { 2 - 5 } & 1 & 2 & 3 & 4 & 5 \\
\hline Physical_Mental_1 & & & & & \\
Physical_Mental_2 & 0.615 & & & & \\
Physical_Mental_3 & 0.770 & & & & \\
Physical_Mental_4 & 0.771 & & & & \\
Physical_Mental_5 & 0.586 & & & & \\
Pleasant_Outdoor_1 & & & & 0.685 & \\
Pleasant_Outdoor_2 & & 0.632 & & & \\
Pleasant_Outdoor_3 & & 0.702 & & & \\
Pleasant_Outdoor_4 & & .511 & & & \\
Pleasant_Outdoor_5 & & & & 0.633 & \\
Pleasant_Outdoor_6 & & 0.701 & & & \\
Learning_Motivation_1 & & & 0.794 & & \\
Learning_Motivation_2 & & & 0.793 & & \\
Social_Eating_1 & & & & 0.530 & \\
Social_Eating_2 & & & & .561 & \\
Suitable_Studying_1 & & & & & 0.610 \\
Suitable_Studying 2 & & & & & 0.817 \\
\hline
\end{tabular}

On the other hand, the factor analysis were conducted on both questions of independent and dependent variables, and they had loaded two items or more in multi factors for each variable by which it was concluded that both variables have the multidimensionality features.

\subsection{Reliability Test}

Reliability test is assessing how much reliable are the items or questions of any variable when measuring the same variable. The measure (group of items) can be considered as reliable if it gets same outcome under consistent conditions. With the statistical analysis, it is the normal way to consider reliability by adopting the concept that items of any questionnaire should have consistency within the entire questionnaire [33]. Cronbach Alpha test was conducted to assess the items' reliability which represent the dimensions of the research variables. Suliman [34] has considered the minimum value for reliability in his work as 0.6, which was taken on in this study as well. Table - 5 shows the results of reliability test applied on the items filtered and resulted by factor analysis which was conducted in section (4.2). Upon conducting the reliability test it was found that the items which represent the three factors of Independent variable were reliable with reliability values as stated in Table 5. One item from factor "Courtyard Area and Services" was dropped to attain reliability value of $(0.788)$. likewise the reliable items were also reported for the items represented the factors of Dependent variable except the items of factor" Suitable Studying Place" as the reliability value reported was (0.545), hence the factor was dropped totally from the study and excluded from further analysis. Consequently, the entire hypotheses related to this dimension was considered as dropped as well, thus H6-1, H6b and H6-3 could not be established. 
Table 5: Cronbach alpha test for research factors and entire questionnaire.

\begin{tabular}{|c|c|c|c|c|}
\hline \multicolumn{5}{|c|}{ Factors of Independent Global Variable } \\
\hline No & Factor & No. of items & Cronbach Alpha Value & No of dropped items \\
\hline 1 & Courtyard Area and Services & 2 & 0.788 & 1 \\
\hline 2 & $\begin{array}{l}\text { Courtyard Environmental Comfort } \\
\text { and decoration }\end{array}$ & 4 & 0.618 & nil \\
\hline 3 & Courtyard Noise & 2 & 0.724 & nil \\
\hline \multicolumn{5}{|c|}{ Factors of Dependent Global Variable } \\
\hline No & Factor & No. of items & Cronbach Alpha Value & No of dropped items \\
\hline 1 & Physical and Mental Well-being & 4 & 0.777 & Nil \\
\hline 2 & Pleasant Outdoor Place & 4 & 0.737 & Nil \\
\hline 3 & Learning Motivation & 2 & 0.769 & Nil \\
\hline 4 & Social Interacting and Eating Place & 2 & 0.647 & Nil \\
\hline 5 & Suitable Studying Place & 2 & 0.545 & $2 *$ \\
\hline \multicolumn{5}{|c|}{ All questionnaire items } \\
\hline No & Factor & No. of items & Cronbach Alpha Value & No of dropped items \\
\hline 1 & All filtered item & 20 & 0.86 & Nil \\
\hline
\end{tabular}

However, the final filtered items representing the entire questionnaire showed high reliability of 0.860 . for all the variables and the factors, thus they are consistent to conduct regression tests to assess the developed hypotheses.

\subsection{Hypotheses Testing}

Hypotheses can be tested by applying regression tests. The aim is to obtain statistical evidences that either support or reject the developed hypotheses. Regression analysis test was implemented in this section to investigate the relationships between Independent and Dependent global variables and the links between the independent facets with dependents facets. Thus, the regression test and the obtained regression model and its factors can reveal the significance status for each hypothesis or the connection between any variables or factors of this study. $F, t, \mathrm{R}$ and $\mathrm{R}$ square are the important coefficients that explain the regression model [35]. The regression between School Courtyard Design and Student satisfaction was shown in Table-9, " $F$ " value reported to be (120.333) and indicated high significance at a value of $p<0.001$, " $R$ " value was $(0.542)$ so that adjusted " $R$ square" value was (0.292) which means $29.2 \%$ of the variation in Students' Satisfaction was shaped by School Courtyard design. Agreeing with the results obtained from regression tests, hypothesis H1 that stated, "There is a significant link between "School Courtyard Design" and "Student Satisfaction" was established.

Table 9: The regression between School Courtyard Design and Student satisfaction.

\begin{tabular}{|l|l|l|l|l|l|l|l|}
\hline Relationship & F value & $\begin{array}{l}\text { Sig } \\
\text { level }\end{array}$ & R & $\begin{array}{l}\text { Adjusted } \\
\text { R squared }\end{array}$ & Factor & $t^{*}$ & $\beta$ \\
\hline $\begin{array}{l}\text { Student Satisfaction (with) } \\
\text { Courtyard Design }\end{array}$ & 120.333 & $<0.001$ & 0.542 & 0.292 & $\begin{array}{l}\text { School Courtyard } \\
\text { Design }\end{array}$ & 6.966 & 0.542 \\
\hline *t value shows significance of $<.001$ & & & & \\
\hline
\end{tabular}

The results in Table-10 evaluated the set of hypotheses H2-1, H2-2 and H2-3. The regression results between the three Independent factors and "Learning Motivation" as dependent factor was displayed in the same 
table. " $F$ " value of (15.718) showed high significant at a value of $\mathrm{p}<0.001$. " $R$ " value was (0.376) so that adjusted " $R$ square" value was (0.132) which means $13.2 \%$ of variation in "Learning Motivation" was shaped by the three factors of the Independent variable. The $(t)$ value of the independent factor "Courtyard Environmental Comfort and Decoration" was (5.025). This factor had the greatest impact in predicting the "Learning Motivation" with beta value of (0.285). The factor "Courtyard Area and Services" which had $(t)$ value of (3.158) and came in the second place of importance in predicting the Students' "Learning Motivation", its beta value was (0.179). In the meantime, the $(t)$ value of the factor "Courtyard Noise" was $(-0.156)$ with negative impact in predicting the "Learning Motivation" and with beta value of (-0.009).

Table 10: The regression results for the set of hypotheses H2-1, H2-2 and H2-3.

\begin{tabular}{|c|c|c|c|c|c|c|c|c|}
\hline Relationship & $\begin{array}{l}\mathrm{F} \\
\text { value }\end{array}$ & $\begin{array}{l}\text { Sig } \\
\text { level }\end{array}$ & $\mathrm{R}$ & $\begin{array}{l}\text { Adjusted } \\
\text { R square }\end{array}$ & Factor & $\mathrm{t}^{*}$ & $\beta$ & Hypothesis validation \\
\hline \multirow{3}{*}{$\begin{array}{l}\text { Learning } \\
\text { Motivation } \\
\text { (with): }\end{array}$} & \multirow[t]{3}{*}{15.718} & \multirow[t]{3}{*}{$<0.001$} & \multirow[t]{3}{*}{0.376} & \multirow[t]{3}{*}{0.132} & $\begin{array}{l}\text { 1. Courtyard Area and } \\
\text { services }\end{array}$ & 3.158 & 0.179 & $\begin{array}{l}\text { H2-1 was considered as } \\
\text { supported }\end{array}$ \\
\hline & & & & & $\begin{array}{l}\text { 2. Courtyard } \\
\text { Environmental } \\
\text { Comfort \& Decoration }\end{array}$ & 5.025 & 0.285 & $\begin{array}{l}\text { H2-2 was considered as } \\
\text { supported }\end{array}$ \\
\hline & & & & & 3. Courtyard Noise & -0.156 & -0.009 & $\begin{array}{l}\text { H2-3 was considered as } \\
\text { rejected }\end{array}$ \\
\hline
\end{tabular}

Results in Table-11 addressed the validity of the set of hypotheses H3-1, H3-2 and H3-3. The regression results between the three Independent factors and "Physical and Mental Well-being" as dependent factor were displayed in the same table. " $F$ " value of (43.413) showed high significant at a value of $p<0.001$, " $R$ " value was (0.559) so that adjusted " $R$ square" value was $(0.305)$ which means $30.5 \%$ of variation in Students" "Physical and Mental Well-being" was shaped by the three factors of Independent variable. The $(t)$ value of the independent factor "Courtyard Environmental Comfort and Decoration" was (6.883). This factor had the greatest impact in predicting the "Physical and Mental Well-being" with beta value of $(0.350)$. The factor "Courtyard Area and Services" which had $(t)$ value of (6.751) and came in the second place of importance in predicting the Students' "Physical and Mental Well-being", its beta value was (0.343). In the meantime, the $(t)$ value of the factor "Courtyard Noise" was (-1.737) with negative impact in predicting the "Physical and Mental Well-being" with beta value of (-0.085).

Table 11: The validity of the set of hypotheses H3-1, H3-2 and H3-3.

\begin{tabular}{|c|c|c|c|c|c|c|c|c|}
\hline Relationship & $\begin{array}{l}\mathrm{F} \\
\text { value }\end{array}$ & $\begin{array}{l}\text { Sig } \\
\text { level }\end{array}$ & $\mathrm{R}$ & $\begin{array}{l}\text { Adjusted } \\
\text { R square }\end{array}$ & Factor & $\mathrm{t}^{*}$ & $\beta$ & Hypothesis validation \\
\hline \multirow{3}{*}{$\begin{array}{l}\text { Physical } \\
\text { and Mental } \\
\text { well-being } \\
\text { (with): }\end{array}$} & \multirow[t]{3}{*}{43.413} & \multirow[t]{3}{*}{$<0.001$} & \multirow[t]{3}{*}{0.559} & \multirow[t]{3}{*}{0.305} & $\begin{array}{l}\text { 1.Courtyard Area and } \\
\text { services }\end{array}$ & 6.751 & 0.343 & $\begin{array}{l}\text { H3-1 was considered as } \\
\text { supported }\end{array}$ \\
\hline & & & & & $\begin{array}{l}\text { 2.Courtyard } \\
\text { Environmental } \\
\text { Comfort \& Decoration }\end{array}$ & 6.883 & 0.350 & $\begin{array}{l}\text { H3-2 was considered as } \\
\text { supported }\end{array}$ \\
\hline & & & & & 3.Courtyard Noise & -1.737 & -0.085 & $\begin{array}{l}\text { H3-3 was considered as } \\
\text { rejected }\end{array}$ \\
\hline
\end{tabular}

The results of regression test in Table -12 evaluated the set of hypotheses H4-1, H4-2 and H4-3. The regression results between the three Independent factors and "Pleasant Outdoor Space" as dependent factor was displayed in the same table. " $F$ " value of (66.208) showed high significant at a value of $p<0.001$, " $R$ " value was (0.640) so that adjusted " $R$ square" value was (0.403) which means $40.3 \%$ of variation in the courtyard as "Pleasant Outdoor Space" was shaped by the three factors of Independent variable. The $(t)$ value of the independent factor "Courtyard Environmental Comfort and Decoration" was (8.681) with individual 
significance value of $<0.001$. This factor had the greatest impact in predicting the courtyard as "Pleasant Outdoor Space" with beta value of (0.409). The factor "Courtyard Area and Services" which had $(t)$ value of (8.346) and came in the second place of importance in predicting the courtyard as "Pleasant Outdoor Space", with beta value (0.393). In the meantime, the $(t)$ value of the factor "Courtyard Noise" was $(0.836)$ and showed an individual non-significant value of 0.404 with very small beta value of (0.038).

Table :12 Regression test for the set of hypotheses H4-1, H4-2 and H4-3.

\begin{tabular}{|c|c|c|c|c|c|c|c|c|}
\hline Relationship & $F$ value & $\begin{array}{l}\text { Sig } \\
\text { level }\end{array}$ & $\mathrm{R}$ & $\begin{array}{l}\text { Adjusted R } \\
\text { square }\end{array}$ & Factor & $\mathrm{t}^{*}$ & $\beta$ & $\begin{array}{l}\text { Hypothesis } \\
\text { validation }\end{array}$ \\
\hline \multirow[t]{3}{*}{$\begin{array}{l}\text { Pleasant } \\
\text { Outdoor } \\
\text { Space (with) }\end{array}$} & \multirow[t]{3}{*}{66.208} & \multirow[t]{3}{*}{$<0.001$} & \multirow[t]{3}{*}{0.640} & \multirow[t]{3}{*}{0.403} & $\begin{array}{l}\text { 1. Courtyard Area and } \\
\text { services }\end{array}$ & 8.346 & 0.393 & $\begin{array}{l}\text { H4-1 was } \\
\text { considered as } \\
\text { supported }\end{array}$ \\
\hline & & & & & $\begin{array}{l}\text { 2. Courtyard } \\
\text { Environmental } \\
\text { Comfort \& Decoration }\end{array}$ & 8.681 & 0.409 & $\begin{array}{l}\text { H4-2 was } \\
\text { considered as } \\
\text { supported }\end{array}$ \\
\hline & & & & & 3. Courtyard Noise & 0.836 & 0.038 & $\begin{array}{l}\text { H4-3 was } \\
\text { considered as } \\
\text { rejected }\end{array}$ \\
\hline
\end{tabular}

The outcome of regression test shown in Table-13 evaluated the set of hypotheses H5-1, H5-2 and H5-3. The regression results between the three Independent factors and "Suitable place for social interaction and break meal" as dependent factor was displayed in the same table. " $F$ " value of (21.130) showed high significant at a value of $p<0.001$, " $R$ " value was $(0.425)$. so that adjusted " $R$ square" value was $(0.172)$, which means $17.2 \%$ of variation in courtyard as "Suitable place for social interaction and break meal" was shaped by the three factors of the Independent variable, the $(t)$ value of the independent factor "Courtyard Area and Services" was (4.446). This factor had the greatest impact in predicting the courtyard as "Suitable place for social interaction and break meal" with beta value of (0.247). The factor "Courtyard Environmental Comfort and Decoration" which had $(t)$ value of (4.274) and came in the second place of importance in predicting the courtyard as "Suitable place for social interaction and break meal", its beta value was $(0.237)$. Moreover, the $(t)$ value of the factor "Courtyard Noise" was (-3.341) and showed an individual significant value of 0.001 with beta value of (0.179 ).

Table 13: Regression test for the set of hypotheses H5-1, H5-2 and H5-3.

\begin{tabular}{|c|c|c|c|c|c|c|c|c|}
\hline Relationship & $\begin{array}{l}\mathrm{F} \\
\text { value }\end{array}$ & $\begin{array}{l}\text { Sig } \\
\text { level }\end{array}$ & $\mathrm{R}$ & $\begin{array}{l}\text { Adjusted } \\
\mathrm{R} \text { square }\end{array}$ & Factor & $\mathrm{t}^{*}$ & $\beta$ & Hypothesis validation \\
\hline \multirow{3}{*}{$\begin{array}{l}\text { Suitable place for } \\
\text { social interaction } \\
\text { and break meal } \\
\text { (with) }\end{array}$} & \multirow[t]{3}{*}{21.13} & \multirow[t]{3}{*}{$<0.001$} & \multirow[t]{3}{*}{0.425} & \multirow[t]{3}{*}{0.172} & $\begin{array}{l}\text { 1. Courtyard Area } \\
\text { and services }\end{array}$ & 4.446 & 0.247 & $\begin{array}{l}\text { H5-1 was considered } \\
\text { as supported }\end{array}$ \\
\hline & & & & & $\begin{array}{l}\text { 2. Courtyard } \\
\text { Environmental } \\
\text { Comfort \& } \\
\text { Decoration }\end{array}$ & 4.274 & 0.237 & $\begin{array}{l}\text { H5-2 was considered } \\
\text { as supported }\end{array}$ \\
\hline & & & & & 3. Courtyard Noise & -3.341 & -0.179 & $\begin{array}{l}\text { H5-3 was considered } \\
\text { as supported }\end{array}$ \\
\hline
\end{tabular}

The outcomes of the research supported the uniqueness of the study; it gave clear explanation about the student satisfaction dimensions in conjunction with the dimensions of the school courtyard design. In the meanwhile the study had shown that among the three Independent dimensions the "Courtyard Environmental 
Comfort and Decoration", was reported to be the strongest dimension in shaping most of the factors of the "Student Satisfaction". The next strongest one was reported to be the "Courtyard Area and Services". However, the dimension "Courtyard Noise" had no prediction role in most of the factors of "Student Satisfaction" as global variable, but it did predict the dimension "Suitable place for social interaction and break meal" with high significant relationship.

\section{Conclusion}

The research demonstrated an empirical investigation regarding student satisfaction in schools associated with their courtyard design; the investigation has opened the door for better understanding about what are the factors that can make variations in Student satisfaction. The study has shown a statistical evidence that the Courtyard Design can shape the Student Satisfaction, The results showed high relationship significance between the School Courtyard Design and Student Satisfaction so that the courtyard design can shape the student satisfaction as global variable with $29.2 \%$. Moreover, the courtyard design can predict the factors "Learning Motivation" with $13.2 \%$, students" "Physical and Mental Well-being" with 30.5\%, courtyard as "Pleasant Outdoor Space" with $40.3 \%$ and courtyard as "Suitable place for social interaction and break meal" with 17.2 $\%$. Thus, courtyard Design should be considered as an important physical element of the school design beside any other resources contributing positively in the educational process.

Likewise, it has been statistically proved that the Courtyard Area is also playing significant role in shaping all the 'Students' Satisfaction" dimensions, therefor courtyard's area should be designed in a way that it can accommodate the number of students, enable their free movement, reduces the pressure on the crowded areas and allow the students to have suitable physical education, thus mental wellbeing.

Another point to be mentioned is that the courtyard area has influence on the student's perception of the courtyard as a pleasant outdoor space that can provide restful scene and meditation, especially when it had landscape.

On the other hand, "School Courtyard Thermal Comfort and Decoration" is the most important predictor of "Student Satisfaction" and its dimensions. Hence the courtyard should be designed from architecture point of view with the right proportions in terms of length, width, and height of the adjacent masses to enhance the air circulation inside the courtyard. Nevertheless, appropriate decoration should be designed in the courtyard including nice suitable sitting area for the purpose of resting, having break meal, and encouraging students' social interaction. It was clearly reported in the results that the courtyard noise has also significant impact on the social interaction, thus the noise from the students and their activities in the courtyard should be encouraged in order to increase students' socialization and to make the courtyard convenient place for having the break meal.

\section{References}

[1] Mumovic, D. and Santamouris, M. 2009. A handbook of sustainable building design and engineering. London: Earthscan.

[2] Li, X., Zhou, Y., Yu, S., Jia, G., Li, H. and Li, W., 2019. Urban heat island impacts on building energy consumption: A review of approaches and findings. Energy.

[3] Muhaisen, A. and Gadi, M. 2005. Mathematical model for calculating the shaded and sunlit areas in a circular courtyard geometry. Building and Environment 40(12), pp. 1619-1625.

[4] ALAOUI, M.S.H., GURAOUI, K. and BELKASSMI, Y., 2019, July. Numerical and Mathematical Simulation of the Energy Efficiency of Traditional Buildings for Thermal Comfort. In 2019 International Conference of Computer Science and Renewable Energies (ICCSRE) (pp. 1-4). IEEE.

[5] Edwards, B. 2006. Courtyard housing. Abingdon [England]: Taylor \& Francis.

[6] Hausladen, G., Liedl, P. and de Saldanha, M. 2011. Building to Suit the Climate. Basel: De Gruyter.

[7] Salameh, M. and Taleb, H., 2017, April. Courtyard as passive design solution for school buildings in hot area. In World Congress on Civil, Structural, and Environmental Engineering (CSEE'17) Barcelona (Vol. 141, pp. 2371-5294).

[8] SALAMEH, M., 2018. Courtyards as passive design solution for school buildings in hot areas: UAE as a case study (Doctoral dissertation, The British University in Dubai (BUiD)). 
[9] Reynolds, J. 2002. Courtyards. New York, NY: John Wiley.

[10] Koch-Nielsen, H. 2013. Stay Cool. Hoboken: Taylor and Francis.

[11] Rivera-Gómez, C., Diz-Mellado, E., Galán-Marín, C. and López-Cabeza, V., 2019. Tempering potentialbased evaluation of the courtyard microclimate as a combined function of aspect ratio and outdoor temperature. Sustainable Cities and Society, 51, p.101740.

[12] Acosta, I., Navarro, J. and Sendra, J. 2014. Lighting design in courtyards: Predictive method of daylight factors under overcast sky conditions. Renewable Energy 71, pp. 243-254.

[13] Al-Hafith, O., Satish, B.K. and De Wilde, P., 2019, November. The impact of courtyard geometry on its mean radiant temperature.In Journal of Physics: Conference Series (Vol. 1343, No. 1, p. 012022). IOP Publishing.

[14] Brown, R. and Mazzarol, T. 2008. The importance of institutional image to student satisfaction and loyalty within higher education. High Educ 58(1), pp. 81-95.

[15] Grossman, B. and Goodhart, F. 2002. Assessing Student Staff Motivation and Satisfaction to Strengthen Health Education Services. Journal of American College Health 51(1), pp. 38-41.

[16] Beck, B., Taskan, G. and BogenÃ $\S$, Ã . 2013. The effect of courtyard designs on young people, which have been made according to different functional preferences. Food, Agriculture \& Environment Vol.11 (3\&4): $1804-1813.2013$.

[17] Teshnehdel, S., Mirnezami, S., Saber, A., Pourzangbar, A. and Olabi, A.G., 2020. Data-driven and numerical approaches to predict thermal comfort in traditional courtyards. Sustainable Energy Technologies and Assessments, 37, p.100569.

[18] Rigolon, A. (2010), "European Design Types for 21st Century Schools: An Overview", CELE Exchange, Centre for Effective Learning Environments, No. 2010/03, OECD Publishing, Paris.

[19] Martirosyan, N., Saxon, P. and Wanjohi, R. 2014. Student Satisfaction and Academic Performance in Armenian Higher Education. Student Satisfaction and Academic PerformancAmerican International Journal of Contemporary Research Vol. 4 No. 2.

[20] Uline, C. and Tschannen-Moran, M. 2008. The walls speak: the interplay of quality facilities, school climate, and student achievement. Journal of Educational Admin 46(1), pp. 55-73.

[21] Martirosyan, N. (2015). An examination of factors contributing to student satisfaction in Armenian higher education. Intl Jnl of Educational Mgt, 29(2), pp.177-191.

[22] Walden, R. (2016). Schools for the Future. [Online] Google Books.

[23] Gidlöf-Gunnarsson, A. and Öhrström, E. (2010). Attractive "Quiet" Courtyards: A Potential Modifier of Urban Residents' Responses to Road Traffic Noise?. International Journal of Environmental Research and Public Health, 7(9), pp.3359-3375.

[24] Kolozali, R., Kolozali. T.(2016).The Role of the Courtyard in the Establishment of Architecture in Cyprus. Architecture Research: scientific and academic publishing. p-ISSN: 2168-507X e-ISSN: 2168-5088 ; 6(5): 123-130.

[25] Hawker, C. 2012. Physical activity and mental well-being in student nurses. Nurse Education Today 32(3), pp. 325-331.

[26] Markus, B., Malsiah, H., Lim, Y.W. and Tanko, B.L. (2017) Examination of Courtyard Dimensions and Proportions In Universiti Teknologi Malaysia Buildings. International, Journal of Real State Studies (Vol.11, N 2)

[27] Matsuoka, R. 2010. Student performance and high school landscapes: Examining the links. Landscape and Urban Planning 97(4), pp. 273-282.

[28] Lau, S.S. and Yang, F., 2009. Introducing healing gardens into a compact university campus: design natural space to create healthy and sustainable campuses. Landscape Research, 34(1), pp.55-81.

[29] Matsuoka, R. and Kaplan, R. 2008. People needs in the urban landscape: Analysis of Landscape And Urban Planning contributions. Landscape and Urban Planning 84(1), pp. 7-19.

[30] Eddy, A. (2018). Take it outside: the added benefits of school courtyards | Birchwood Design Group. [Online] Birchwooddesigngroup.com. Available at: http://birchwooddesigngroup.com/take-it-outside-theadded-benefits-of-school-courtyards/ [Accessed 2 Jan. 2018]. 
[31] Xue, P., Mak, C.M. and Cheung, H.D., 2014. The effects of daylighting and human behavior on luminous comfort in residential buildings: A questionnaire survey. Building and Environment, 81, pp.51-59.

[32] Berk, K., Voelkl, K. and Gerber, S. 2000. Using SPSS for Windows: Data Analysis and Graphics. The American Statistician 54(1), p. 82.

[33] Anon 2014. Discovering Statistics Using IBM SPSS Statistics. And Sex and Drugs and Rock'n'Roll. Pflege 27(6), pp. 430-430.

[34] Suliman, A. 2001. Work performance: is it one thing or many things? The multidimensionality of performance in a Middle Eastern context. International Journal of Human Resource Management 12(6), pp. 1049-1061

[35] Suliman, A. and Al Kathairi, M. 2012. Organizational justice, commitment and performance in developing countries. Employee Relations 35(1), pp. 98-115. 